\title{
Orientalism on Malay People in Kipling's Limitation of Pambe Serang
}

\author{
Hariyono $^{1}$, Putut Handoko ${ }^{2}$, Sanhari Prawiradiredja ${ }^{3}$, Meithiana Indrasari ${ }^{4}$ \\ \{bagushariyono@gmail.com ${ }^{1}$, putut.handoko@unitomo.ac.id ${ }^{2}$, sanpraw@yahoo.co.id ${ }^{3}$ \} \\ ${ }^{1,2,3,4}$ Dr. Soetomo University, Indonesia
}

\begin{abstract}
This article studies how Orientalism is applied in Rudyard Kipling's short story the Limitation of Pambe Serang. To achieve this goal, this article studies the idea of Orientalism as proposed by Edward Said (1978). The result of this paper can be described that Kipling represents the main character of the story, Pambe Serang, a Malay sailor, as good Malay, that according to Kipling, the definition of a good Malay as someone that cannot easily forget a bad deed that disturbs him, so that he waits for revenge if a change takes place. This representation of orient, Pambe Serang, as a vengeful person is a stereotype that is held by Kipling, as a proof that western authors at the peak of imperialism represent the oriental peoples as they want to.
\end{abstract}

Keywords: Orientalism, Malay people, Kipling's.

\section{Introduction}

The advanced civilization of the western peoples have taken place for centuries have the effects other peoples in many parts of the world, through the use of technology and values that have been made during the contacts between the western people and the other peoples of the world. The previous events of colonialism and imperialism, as cultural products, can be found as well in literary works. Literary works, like other cultural works, are regarded as artifacts of a community by the following generations that convey their subjective experience in understanding their worldview.

During the peak of the western imperialism almost completely in the global area, the western authors, as Edward Said [1] said that they became the active agents of the imperialist tools in governing the native population. Said emphasized that the authors served the interests of the colonial powers because they sought a career in the orient, as the Orient is a career. Said also said that during the history of colonialism and imperialism, the doers of imperialism never think that they are wrong, because they think that they come for a good purpose, "Every empire, however, tells itself and the world, that it is unlike all other empires, that its mission is not to plunder and control, but to educate and liberate". The quotation is a good illustration how from the western point of view what they did in the many parts of the world and how they described peoples in many parts of the world was objective and unbiased, is basically under strong criticism because it ignores the view of the non-western people.

The western authors were also handed in hand with the colonial sides in portraying the oriental people in a stereotypical way, in which Said said about the western's distortion on the 
orient peoples as, "Oriental despotism, Oriental sensuality" [1]. The negative portrayal of the oriental people as a part of stereotyping that is disseminated in western society to serve the imagination of other peoples, and then it is known as the others. Stereotyping of the oriental people becomes a discourse that legitimates the control of the so-called "the uncivilized" peoples.

The phenomenon of the stereotyping of the oriental people or the others that were or are written can be found in literary works, as literary works are the mirror of society. As the products of human beings in a certain period of time, literary works are closely related to the time when the works are created [2]. This happens for the literary works are created by the authors as a means to gain a self-portrayal of the thoughts of the authors in responding to their problems in a specific time.

Within this context, western authors, especially from the Great Britain and France, during the peak of western colonialism until the $20^{\text {th }}$ century represent the interest of the western people because the emergence of the critical other world authors, such as Ngugi Wa Thiongo (Kenya), Chinua Achebe (Nigeria), and Pramudya Ananta Toer (Indonesia), Said gives some prominent western authors that show the bias and stereotyping of the "uncivilized" others, some of them are Rudyard Kipling, Joseph Conrad, and even George Orwell.

While Joseph Conrad, criticized both imperialism and praised it as a legal thing to be conducted to the uncivilized African peoples, Rudyard Kipling is seen as a western author that without critical thinking justifies and mystifies the imperialism in what he sees as the exotic east. Kipling is famous for his firm staunch of the superiority of western people, especially through his poem stating that

"OH, East is East, and West is West, and never the twain shall meet,. Till Earth and Sky stand presently at God's great Judgment Seat".

This poem shows how Kipling feels how the western mentality is completely different from the eats'. Rudyard Kipling (1865-1936), the author that becomes the object of the discussion in this paper is famous for his work The Jungle Book and praised even as the Nobel Prize winner in literature (but strangely not Joseph Conrad). Kipling also writes other books, such as Kim and the Limitation of Pambe Serang (1889). While on the Jungle Book and Kim, Kipling writes about India from the point of view of western people, and therefore he inserts his representation of orientalism, but on the Limitation of Pambe Serang, he writes on the scene of Nusantara, where he represents a native Malay sailor, namely Pambe Serang. Because of the involvement of character coming from the Malay background, the researchers feel interested in studying the phenomenon of Orientalism in the Limitation of Pambe Serang.

This paper has a statement of the problem on how the idea of orientalism is described in Rudyard Kipling's short story the Limitation of Pambe Serang. As, the "the oriental" people, the researchers find the facts that through the literary works in the form of representations, western authors use a stereotype to describe the others. 


\section{Theoretical Background}

The discourse of orientalism as Ashcroft explains the idea of Said as a representation of the orient politically, sociologically, militarily, ideologically, scientifically, and imaginatively during the post-Enlightenment era [3] and it is very ironic, while on one hand, the enlightenment brought a much better understanding about the objectivity, and it led to the scientific advance to the western society, but on another, there was or is strong self- representation on others. This condition is a discourse project that is used to divide the world into two camps, the western civilized and the others are not so that it is easily a binary opposition. This discourse is justified as a means to educate and civilize the savage and uncivilized the others. Under the circumstances, hegemony and specific discourse are elaborated to maintain the portrayal objects.

The term orientalism is spread by Edward Said, a prominent literary critic from Palestine origin. He was born as an Arab Palestinian Christian in Jerusalem which was part of the British colonial rule at the time. His own bitter experience as a Palestinian that feels treated unjustly by the big power countries that made him lose his big house in Jerusalem during his childhood in 1948 war. He studied in the USA and got his professorship there and started his popularity after publishing his idea on orientalism. Said explored that behind their claim of objectivity, the western authors were basically part of the agents of Western colonialism, so that their writings described the misrepresentation on the other peoples that lived under the realm of western people in Asia, Africa, and Latin America. He wrote his idea on his book Orientalism, written in 1978 that triggered wide praise and objection. For Said, oriental is not reality, but it is a construction that is made by the western people with their interest to keep exploiting the others. The contribution of Edward Said on the field of literary criticism is that he is one of the pioneers that is called as the postcolonial paradigm, as a developer of the idea of Foucault on the post-structuralism.

Foucault and Gramsci as cited by Said in Orientalism, show that culture is under the control of the owners of power. The uncontested power and hegemony work hand in hand with the values that are injected by the ruling class. Considering this, Foucault uses counter-discourse and Gramsci uses anti hegemony. Foucault states by doing this as "the death of representation". The representation is used by the western people to maintain their so-called objective research at the time, things that are under-challenged by a paradigm of post-colonialism, a term that is designated to confront the legacy of western colonialism [4]. The growing numbers of experts that are very critical with the represent the others can be found on the works of Edward Said, Gayatri Spivak, Homi Bhabha, Bill Ashcroft, Chinua Achebe, Ali Mazrui, Ngugi Wa Thiongo, etc. They challenge what the western authors called the objectivity of the truth that is grounded on the western tradition. In facts, the western authors, they are the active agents of the western colonial apparatus that join the colonial interests; they represent the oriental people as misrepresentation. More the western authors get involved in the matters of colonial interests, so their works get more misrepresentation of the so-called oriental peoples [5].

Orientalism is an invention created by the western mind as an entity that differs from them, in which Said uses the term "us" and "those" 1978. This specific awareness that holds the mind of the western authors as a part of the ruling class happens when they represent the orient or oriental things. Ashcroft states that an essential feature of orientalism is the objectification of both the orient and orientalism. They must be treated as objects that can be scrutinized and understood and confirmed in the term 'orient' [3]. 
From the explanations, it can be said that the causal factor that can make the occurrences of orientalism take place is the superiority complex that the western authors have at the time of colonialism. This superiority complex makes them feel that western civilization is much more civilized than the rest of the world, things that lead to the idea of Eurocentrism. Eurocentrism leads to an ideology of binary opposition that sees the others as inferior. Because of the feeling, orientalism can be described in the forms of representation, justified colonialism, and stereotyping on others. Orientalism gives impacts on others through the on and on the destruction of the traditional values of the "oriental" peoples, representation, and stereotyping.

Orientalism in a certain degree of influence still takes place in some cases, as the binary opposition still happens. Even, it is made more sophisticated by using other masks, in which the famous book the Clash of Civilizations and the Remaking of World Order written by the late Professor Samuel Huntington is one of the examples. Instead of trying to dissolve the barrier between east and west, Huntington sharpens the divisions. In fact, his idea is widely challenged. By dividing the peoples into some criteria of cultural background that shows his hidden motives of maintaining power, Huntington has many flaws of systemizing his idea that cannot compatible with the facts.

\section{Analysis}

The short story of the Limitation of Pambe Serang was written in 1889 by Rudyard Kipling, a British author, who has experienced living in India that was still under the occupation of the British Maharaj. Kipling describes the situation of sailor men that live during the journey on the sea. All of the sailormen work aboard on the ship of Saarbrucken that sails to Aden, a port in Yemen. Kipling describes the life of the crew that comes from much oriental crew with their backward mentality. The two prominent crew are Nurkeed, a black Zanzibari man, a tall and curly hair man, and another is Pambe Serang is Malay sailor. Kipling gives a description on where Pambe Serang hails from. Pambe Serang is a Malay, born in India that marries once to a Burmese woman, once in Singapore, to a Chinese girl, and once to Muslim girl [6] in Madras, India. Kipling gives a notion that serang is rank among the crew that is higher than a stoker, the job that Nurkeed holds.

The problem happens when the big and black man, Nurkeed steals a canteen of food that belongs to Pambe Serang. Nurked enjoys the meal even without using a spoon after he works hard dealing with the hot fire and coal. Pambe catches him in action so that he is very angry, even worse Nurkeed stabs him and hits his leg with a knife. The confrontation does not last long because an officer, a white man sees the event, and they separate. The problem comes as Kipling stresses that a Malay like Pambe as:

"Pambe was a good husband when he happened to remember the existence of a wife, but he was also a very good Malay; and it is not wise to offend a Malay because he does not forget anything (TLoPS:53).

The above quotation shows the intention on how Kipling wants to represent the typical "good" Malay that he wants to portray, the good Malay(s), in general, are the people who do not forgive easily and are vengeful. This imagination about the oriental people, in this case, is Malay, shows that Kipling has an assumption that is rooted in superiority complex that Malays are unforgiving people. Kipling stresses by his own imagination that the characteristics of being 
unforgiving people are deeply embedded in the concept of instinct that is inherited passed from one generation to another generation, by using the word the "good Malay". Kipling uses the standard of valuing the goodness of being Malay enough is seen from his eagerness to keep the value of taking revenge. Someone that hails from a Malay circumstance or environment cannot be Malay enough if he forgives somebody, so very typical Malay that is constructed in the mind of Kipling is from the degree of revenge.

This stereotyping of orientalizing the orient people can be worse when Kipling compares the superiority of himself and the character of Pambe Serang that he dramatizes. It is not a coincidence if he compares himself and Pambe Serang. Kipling was born in India at the time of the British Maharaj, as by design he portrays that Pambe is also born in India (TLoPS, p.53). Both, one is real and another is fictitious, were born in India, and one represents a pearl in the middle of thrash, while another is a thrash born in the jungle of thrash. Kipling was proud to be a "civilized" western man that lived among the uncivilized Hindus and Muslims in India, like a pearl among thrash.

When he describes that the instinct of taking revenge is a genetic problem of Malays, by his referring that Pambe was born in India, but he still he is vengeful. From this explanation, Kipling does not practice stereotype but he also puts a racial prejudice that genetically the Malays, wherever they are born, they still the problem of revenge within their blood. This racial description is in line with his own self- description that even though he was born in India, he insists that he still belongs to the British motherland, not the despicable race of Indian peoples.

Then, Kipling explores how contrast life of Nurkeed and Pambe. While Nurkeed cannot remember a face and forgets the accident, Pambe still always tries to take revenge whenever he has a chance to do that. Two times Pambe tries to take the life of Nurkeed but never succeeds. Whenever Nurkeed works in different ships, Pambe still tries to locate where about Nurkeed is. Until one day, when Pambe is lying on the bed in a room in London because he is sick, and cannot bear the sickness, he hears the voice of Nurkeed and when people try to help him, Pambe asks to bring Nurkeed to get inside close to him. The western people as Kipling portrays in the scene as the people that understand the need of the dying Pambe without realizing the bad intention of the vengeful Malay, Pambe Serang, who even in his dying condition still thinks about taking revenge. The following quotation describes the condition when the dying Pambe asks people to call Nurkeed to in order to get closer to him:

"He wanted one of his own race," said the kind gentleman, and going out, he called "Nurkeed!" at the top of his voice" (TLoPS,p.55).

The quotation shows that Kipling represents his own race as "the kind gentleman" that means he gives a good value of how a western man has good moral that helps a dying man, but on the contrary, the dying main is very low morale. Even though he is dying, he is still thinking about how to take revenge, because he is good Malay that always tries to find a way to take revenge. This representation shows the typical stereotyping characters in Kipling's stories that show that western characters have a better moral quality than the oriental characters. This view is a kind of misrepresentation as to a kind of generalization that implies the powerful western authors can describe the oriental characters as they wish.

Kipling also uses the word "oriental" in this line:

"how these Orientals love like children" 
The quotation means that the white man has a very good intention, and do not have bad intention like a Malay, an oriental man, that his good action is merely a mask of doing a hidden intention.

When finally Pambe Serang makes Nurkeed get closer to him, Pambe stabs him and kills him, and he says, "Now, I can die". This statement shows that a good intention of an oriental is basically a camouflage for he hides the real intention. This view as Said sees has been common at the peak of colonialism, as the mentality of corrupt and despotic mind of the oriental people, the accusation that is basically rooted in the racial idea of superiority complex that has been held by the western mind in projecting the people that they consider as oriental.

\section{Conclusion}

As stated in the introduction, that this article tries to describe how orientalism is applied in Kipling's short story of the Limitation of Pambe Serang, and The result of this paper can be described that Kipling represents the main character of the story, Pambe Serang, a Malay sailor, as a good Malay, that according to Kipling, the definition of a good Malay as someone that cannot easily forget a bad deed that disturbs him, so that he waits for a revenge if a change takes place. This representation of orient, Pambe Serang, as a vengeful person is a stereotype that is held by Kipling, as a proof that western authors at the peak of imperialism represent the oriental peoples as they want to.

As a suggestion, the article hopes that by revealing the existence of orientalism in the classic work of a great author, Kipling, it can be a contribution for understanding better about the humanity that shares the same planet, so that the racial prejudice can be blocked because the world becomes more global and the interdependency is much more important than the old type of colonialism that is rooted the superiority and inferiority complex relation. Boundary of western and oriental lines have been challenged now, as more effective workers from "the inferior race" are threating Trump in the domestic problem and became his campaign theme, and the oriental China and India now are much threating than the same western countries competing in the past for the "superior" western nations.

\section{References}

[1] E. Said, "Said -- Orientalism, Introduction.pdf," Orientalism. 1978.

[2] O. Winarti, "Language Shift of Krama to Bahasa Indonesia among Javanese Youths and it's Relation to Parents' Social Class," J. Stud. Komun. (Indonesian J. Commun. Stud., 2018.

[3] B. Ashcroft and P. Ahluwalia, Edward Said - Routledge Critical Thinkers. 1999.

[4] D. Geall, “ A Said Dictionary201396R. Radhakrishnan. A Said Dictionary . Malden, MA, and Oxford: Wiley - Blackwell 2012. xvii+175 pp., ISBN: 9781405183789 (hbck); 9781 405183772 (pbck) £50, \$79.95 (hbck); £19.99, \$34.95 (pbck), " Ref. Rev., 2014.

[5] E. W. Said, Power, politics, and culture. Vintage, 2007.

[6] R. Kipling, 7 best short stories by Rudyard Kipling, vol. 4. Tacet Books, 2018. 